\title{
Public Enterprises in Kosovo and Their Challenges in the Future
}

Bahri Hyseni

NPH Ibër-Lepenc, Sh.A.,e-mail:bahrihyseni@yahoo.com

Magdalena Bregasi

Universiteti Europian i Tiranës, magdalena.bregasi@uet.edu.al

Metë Beqiraj

KorporataElektroenergjetike e Kosovës, Sh.A., m_beqiraj_1@hotmail.com

Doi:10.5901/ajis.2014.v3n2p63

\section{Abstract}

Public enterprises in Kosovo have this form of organization from 2009, even though most of them have existed earlier and have performed their activity as socially owned enterprises. We can distinguish four important periods that influenced their development: the period of establishment and operation in an economy with a socially owned enterprises, the period of 19901999 characterized by galloping inflation and destruction of assets with minimal utilization of capacity, the period of 2000-2007 or the administration of public enterprises by former Kosovo Trust Agency (KTA ), their transformation into public enterprises, and the period from 2008 or after the implementation of the Law on public enterprises in Kosovo ( Law no . 03/L-087 ). Public enterprises in Kosovo nowadays are facing numerous challenges including: changing the form of government, introduction of public-private partnership, monopoly, regulation or free formation of prices, privatization or changes in their organizational form, and saving the independent status from the political influence. Almost all public enterprises in Kosovo are having difficulties with revenues which will ensure the development of their activity. Therefore, based on the current situation, public enterprises in Kosovo must prepare to face these challenges and have to find solutions that will help the managements of the public enterprises to meet the minimal requirements which will directly increase the level of services to citizens.

Keywords: public enterprises, challenges, organization, administration, governance, services

\section{Public Enterprises in Kosovo and Their Challenges in the Future}

Public enterprises in Kosovo are a continuation of former SOEs in terms of the activities they perform today but with substantial difference represented in their way of governance. Former governance is replaced with corporate governance as far more advanced form of organization in the global economy. Normally as any other form of governance even the corporate governance has its own challenges. These challenges usually are present during the implementation new form of the governance as well as the organization and development of enterprise in the future. Based on the experiences they are having more and more challenges are related with the requests they have. In this sense, the purpose of the paper is to analyze available data and experiences of public enterprises, and to emphasize the challenges without pretending to give a solution for them. Our contribution lies in providing assistance in the theoretical description and to inform all those who run public enterprises, shareholders and clients of services provided by public enterprises. Early recognition of the challenges they will face in the future provide a further opportunity to overcome them successful. We believe that successfully or not successfully coping with the challenges in the future will determine their further development but also the level of public services to be provided.

\section{The Formation of Public Enterprises and Corporate Governance}

Former SOEs which were administered by the Kosovo Trust Agency (KTA), but as the Law on Public Enterprises in Kosovo (Law Nr.03/L-087) went into a force there were formed public enterprises. The goal of this law was as in the following:

1. Establishment of legal framework for regulation of property rights 
2. Corporate governance of companies in accordance with internationally recognized principles for corporate governance of public enterprises

3. To establish effective reporting and accountability for appropriate monitoring of the activities of public enterprises.

All public companies under this Law shall be organized as a joint stock company in accordance with the Company Law (Law No.02/L-123).

According to the activity and geographic expansion in the provision of services public enterprises are grouped in central, regional and local public enterprises. Under this law, the central public enterprises are owned by the Republic of Kosovo and the Government has exclusive jurisdiction to exercise the rights of shareholders whereas the rights of shareholders in a public enterprises where the municipality is shareholding carries Municipal Committee Shareholders. In accordance with the requirements of the law mentioned above, in public enterprises it is organized and implemented corporate governance.

\section{Challenges}

\subsection{Completion of the Boards of Directors}

Despite inexperience and difficulties, after the formation of public enterprises in 2008, there were initiated procedures for the selection of Boards of Directors for public enterprises. This process of selecting board of directors has been politically influenced because in their compositions there are persons appointed by political parties in the ruling coalition. Due to conflict of interest as board directors were selected, some of these directors with the decision of the Kosovo AntiCorruption Agency were forced to resign from the board of director positions. The government came up twice with vacancy announcements for the admission of new directors but so far it is known that the first vacancy announcement is canceled, but the second vacancy announcement is open since April of last year and so there is no information regarding the current status. After the vacancy announcement was closed, the new Board of Directors in PTK was appointed by the government with decision No. 27/62 dated 27.12.2013. Because the mandate for these boards has expired, the government came up with a decision to extend the mandate as long as another decision is not made for the board of directors who had no reason to resign (Nr.27/53 decision of date 21.12.2011). Now some of these boards are incomplete but they continue to function in this way. In the selection process for these boards it is not respected the criterion of gender structure and criterion of community representation. One of the main challenges in the governance of public enterprises except competition of Board of Directors remains the selection of people with professional background according to criteria set by the Law on Public Enterprises in Kosovo, and de-politicization of the board of directors as decision-making bodies.

\subsection{Lack of experience in corporate governance}

Corporate governance as a form of governance in the enterprise was not applied earlier. In the public sector in Kosovo, corporate governance has been practically implemented after the approval of the Law on Public Enterprises in Kosovo (Law Nr.03/L-087). Therefore difficulties arising during the governance are due to inexperience of the members of the Board of Directors, officers and senior management. Method of selection for board members has resulted in disregarding the selection criteria for professional and academic background and therefore their success in corporate governance has been limited.

\subsection{Strengthening supervision from PAMU of public enterprises}

According to the Law on Public Enterprises in Kosovo (Nr.03/L-087 Law, Article 7), supervision of public enterprises is assigned only to shareholders of Policy and Monitoring Unit of Public Enterprises (PAMU) which under Article 37 of the same law established by the Minister in the Ministry for the purpose of supporting the Minister and the Government in its responsibilities for public enterprises that are directed to them by this law. The initial human capacity for Unit is not adapted to periodic changes that are made to public enterprises as their numbers increase, the change - creation of new enterprises, etc. Therefore for the function of conducting proper supervision of public enterprises it is required by NJPPM to hire additional professional staff in accordance with the needs and assessment information to support the respective Ministry. 


\subsection{Reorganization of public enterprises}

In order to increase the quality of public services, performing more efficiently and having lower costs, some public enterprises will be challenged by new forms of organization. In some countries have public enterprises have changed their organizational forms by selling shares, being privatized and have implemented a public-private partnership concession like Prishtina International Airport. Since May of last year, Kosovo Company for Distribution and Supply of Electricity (KEDS) has already started to function as a separated privatized enterprise, part of the former KEK Distribution. Although there is no analysis by a third party rather we have efficiency increased in electricity distribution in comparison with the time it worked as part of KEK, KEDS sources are stating that is has increased the level of income collection whereas we have a decreased losses as a result of management commitment and changes in the form of governance. Reorganization of public enterprises in the form in which they will provide better services to the public is one of the most important challenges that must be resolved.

\subsection{Increased levels of revenue collection}

Some of the public enterprises that provide public services are facing difficulties on revenue collection. This is one of the main problems for which public enterprises cannot find a solution. Solving the problem of revenue collection is not only the solution of the adequacy of financial resources but also for the problems which are caused by lack of inputs to insolvency at its most fierce. Despite the efforts of managements only the power supply sector has improved the collection of revenues whereas the water supply sector and the waste management sector have relevant difficulties in revenues collection. This is one of the most difficult challenges that must be solved because in its successful solution it is depended the quality of public services and solution for many other problems that accompany it. So far, the Government through the Ministry of Economic and Development and Unit for Policies and Monitoring has helped public enterprises with capital investment funding, to subsidize losses on lending for technological and interventional situation (KEK case import of energy subsidies for debts or social strata).

\subsection{Implementation and harmonization of laws}

Since their formation in 2008 until now, the governance of public enterprises is regulated by two laws: the Law on Commercial Companies and the Law on the Public Enterprises in Kosovo (Nr.03/L-087 Law) and Law no. 04/L-111 Amending the Law no. 03/L-087 for Public Enterprises.

\subsection{Environmental requirements}

Some public enterprises from the energy, water and waste management sector in the near future will be faced with environmental criteria which must be met as a result of requirements to protect the environment from pollution, increasing water quality, cleanliness and waste disposal. Thus, the energy sector has to meet the requirements for limiting air pollution and limiting the presence of carbon dioxide in the air. These are some of the challenges which are unlikely to be implemented because of the level of technology in the production of electricity. Water supply sector is facing demands for an increased level of quality drinking water while waste sector is facing demands for separation of waste based on composition.

\section{Recommendations and Conclusions}

Based on the current trends, public enterprises in Kosovo in short period of time will face some of the challenges that we have mentioned above. Some of them can overcome difficulties and challenges by adhering the requirements of applicable laws, by changing and adapting policies for appropriate purposes, whereas current technical and technological development is not at the level that will make changes and meet the environmental requirement protection and quality assurance.

Some of the key recommendations that may help in dealing with some of the challenges in the future are: First, the selection of boards of directors by implementing legal requirements practically professional background and personal skills before the political interference. Secondly, public enterprises should go with continuous improvement in corporate governance deficiencies considering the inexperience of board members and senior officials in corporate governance. 
Third, almost all public enterprises have difficulties in the collection of the revenues for public services, especially water supply, electricity and waste management. Therefore this challenge requires to be treated carefully with the aim of resolving the problem of revenue collection. Fourth, the government, the Ministry of Economy and Development, Boards of Directors and senior officials should take into consideration the requirements for environmental protection because they are an important factor for the integration processes in the EU. We consider that dealing with some of the challenges that public enterprises will face in the future will have an impact on their performance and the quality of services provided.

\section{References}

Bank, T. W. (Janary 2013). Kosovo Country Environmental Analysis. The World Bank.

Deloitte. http://www.kek-energy.com/rapFinanca.asp. 31 December 2010. 20 August 2012 <http://www.kekenergy.com/doc/publikime IDelloitte\%20\%20raporti\%20financiar\%20UNBUNDLED\%20per\%20vitin\%20\%2031\%20dhjetor\%202010.pdf>.

Deloitte. http://www.kek-energy.com/rapFinanca.asp. 31 December 2009. 20 August 2012 <http://www.kekenergy.com/doc/publikime /Raporti\%20i\%20auditorit\%20t\%C3\%AB\%20pa varur\%2031dhjetor\%202009.pdf>.

Ekonomik, R. e. (2011). Raporti i Performancës së Ndërmarrjeve Publike 2010. Prishtine: Ministria e Zhvillimit Ekonomik.

Instituti Kosovar për Kërkime dhe Zhvillim të Politikave. (2011). Menaxhimi publik: Analizë e bordeve të ndërmarrjeve publike dhe agjencive të pavarura. Prishtine: KIPRED.

Jocelyn, T. (2003), "Accountability and Audit".International Journal of Government Audit. Vol. 30, No. 2, April.

Johnson, I. E. (1996), Public Sector Accounting and Financial Control. Surulere: Financial Training Nigeria, $2^{\text {nd }}$ Edition.

KOSOVO, S. A. (2011). Series 3: Economic Statistics - Statistical Repertoire of Enterprises. Prishtine: Statistical Agency Of Kosovo.

KOSOVËS, K. E. (Janar 2012). Raporti per Performancen per Vitin 2011. Prishtine: Korporata Energjetike E Kosovës .

"Prishtina" sh.a, K. e. (March 2013). Raporti Vjetor KRU Prishtina 2012. Prishtine: Kompania e Ujesjellesit Regjional "Prishtina"sh.a.

Republic of Kosovo- Assembly . (n.d.). Law No. 03/L-087 On Publicly Owned Enterprises. Retrieved March 29, 2014, from http://www.assembly-kosova.org: http://www.assembly-kosova.org/common/docs/ligjet/2008_03-L087_en.pdf

Thornton, G. (2011, December 31). http://www.kek-energy.com/rapFinanca.asp. Retrieved March 20,012fromhttp://www.kekenergy.com /doc/publikime/KEK\%20 Pasqyrat\%20Financiare\%20 2011\% 20ALB.PDF

Tušek, P. d. (2007). The Role of Internal Auditing in the Increase of Business Quality of Enterprises in the Republic of Croatia Empirical Research. Zagreb: Zbornik Ekonomskog fakulteta u Zagrebu. 